\title{
Biomarkers of pollution in soils irrigated with wastewater in Tunisia
}

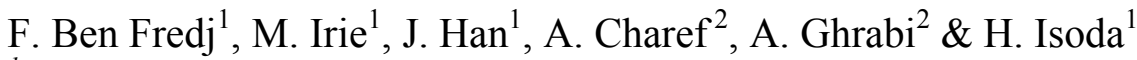 \\ ${ }^{1}$ Graduate School of Life and Environmental Sciences, \\ University of Tsukuba, Japan \\ ${ }^{2}$ Water Researches and Technologies Center, \\ Technopark of Borj-Cedria, Tunisia
}

\begin{abstract}
Wastewater reuse for irrigation is expected in the Mediterranean basin as a sustainable alternative with socio-economic benefits. However, wastewater carries considerable amounts of harmful chemicals and trace toxic metals that are able to accumulate in soil. This pollution loading is threatening both the vegetation and the groundwater and, consequently, human health. Therefore, in this study, in vitro bioassays were used to evaluate the adverse effects of wastewater and soil extract samples, on mammalian cells, with respect to heavy metal content $(\mathrm{Ni}, \mathrm{Cd}, \mathrm{Pb}, \mathrm{Fe}$ and $\mathrm{Al})$. The irrigation water, from a wastewater treatment plant, was sampled at Zaouit-Sousse perimeter in Tunisia. A representative soil profile irrigated with wastewater $(0-90 \mathrm{~cm})$ and a nonirrigated profile $(0-40 \mathrm{~cm})$, serving as a control, were sampled in the olive-treeoccupied perimeter. The estrogenic activity of the samples was investigated using the E-screen assay, while the heat shock protein (HSP) 47 assay aimed to determine the stress response of HSP 47-promoter-transfected cells following sample addition. Furthermore, proteomics analyses were performed, aiming to establish specific biomarkers of environmental pollutants. The irrigation water samples induced a high estrogenic activity when the MCF-7 cells were treated at $10 \%$ due to the presence of estrogenic compounds. The E-screen assay revealed a cytotoxic effect of the surface soil samples $(0-20 \mathrm{~cm})$, even at low concentrations $(0.001 \%)$. Furthermore, the proteomics experiments allowed the identification of specific biomarkers for estrogenicity and cytotoxicity on MCF-7 cells. Moreover, significant stress response was observed following the incubations of the HSP 47-promoter-transfected cells with wastewater samples,
\end{abstract}


even at $0.1 \%$, and soil extracts $(0-60 \mathrm{~cm})$ at concentrations as low as $1 \%$. Interestingly, no stress response or cytotoxic effect was observed for the control soil or for deep layers below $60 \mathrm{~cm}$. These biological techniques could be extremely useful to evaluate the impact of wastewater reuse.

Keywords: biomarkers-wastewater reuse-heavy metals-in vitro bioassays.

\section{Introduction}

Water resources are severely limited in most countries in the Mediterranean region. This water scarcity has led to the development of non-conventional resources in order to satisfy a sharply increasing water demand, mainly for irrigation. Therefore, wastewater reuse for irrigation became a common reality in the Mediterranean basin as an important aspect of integrated water resources management [1]. Tunisia is in a situation of hydrous stress with less than 1000 $\mathrm{m} 3 / \mathrm{inh}$ yr, is facing an arid and semi-arid climate with an uneven rainfall distribution and long drought periods. Consequently, an ambitious national wastewater reuse policy was launched at the beginning of the 1980s. The rate of reclaimed water reuse for irrigation or groundwater recharge, $30 \%$ of the available water, is still low compared to the potential target of $60 \%$ by 2016 [2].

Despite the potential socio-economic benefits derived from wastewater reuse, this kind of irrigation is often associated with environmental and health risks. It contains considerable amounts of harmful chemicals and traces of toxic metals that are able to deteriorate the soil, accumulate in plants or contaminate the groundwater. These harmful compounds represent a potential risk for the environment and human health through the food chain. Hence, adequate precautions should be taken prior to irrigation with treated wastewater (TWW). Guidelines for the reuse of TWW focus on defining appropriate levels of treatment needed for different types of reuse [3]. Several pollution indicators, such as the physico-chemical parameters (BOD, SS, chlorine, phosphates, nitrates), pesticides, heavy metals, fecal coliforms or intestinal nematodes, are widely under use. Restrictions on the allowed crops to be irrigated depend on the level of treatment and include vegetables, trees, cereals, grasslands, public gardens and golf courses [1].

Previous studies focused on physico-chemical parameters, heavy metal content and bacterial indicators to assess the potential hazard related to wastewater reuse for irrigation purposes. Gupta et al. [4] detected heavy metal content in wastewater and soil, higher than local standard guidelines, in order to judge the suitability of the water for irrigation. Al-Khashman [5] investigated the chemical composition of sewage effluents by analyzing major ions and trace metals. Fitting the guidelines for irrigation water served to consider that the TWW is suitable for irrigation purposes. Palese et al. [6] analyzed TWW and wetted soil samples for fecal contamination. Escheriachia coli, Salmonella and Enterococci concentrations in the wastewater, soil or fruits were compared to the stringent Italian or WHO mandatory limits. Most of the previous studies assumed that the potential risk to humans is conveyed by the food chain. Therefore, the direct assessment of wastewater reuse on mammalian cells 
deserves a great interest in order to investigate the potential biological effects and to establish specific biomarkers of wastewater reuse pollution.

The present study focused on evaluating the hazardous risk related to wastewater reuse for irrigation in a semi-arid area in Tunisia. The objective of the study was to investigate the estrogenic activity and the stress response of the reused TWW and the irrigated soil with regard to its heavy metal content. Furthermore, proteomics analyses were performed, aiming to establish specific biomarkers of wastewater reuse pollution.

\section{Materials and methods}

\subsection{Sampling site}

The irrigated perimeter of Zaouit Sousse $\left(\right.$ lat $=\mathrm{N} 35^{\circ} 46^{\prime} 37.2^{\prime \prime}$, long = E10 $39^{\prime} 9.3^{\prime \prime}$ and altitude $=20 \mathrm{~m} \mathrm{N.G.T)}$ is located in the south of Sousse city, Tunisia, fig.1. It is situated $7.5 \mathrm{~km}$ from Sousse South sewage treatment plant (STP), which uses trickling filters coupled to an activated sludge system, with a treatment capacity of $18700 \mathrm{~m}^{3}$ wastewater per day. The wastewater effluents are mainly reused for the irrigation of olive trees surrounded by sorghum in summer and bersim in winter. The surface irrigation started 20 years ago.

\subsection{Water quality parameters}

A representative $1.5 \mathrm{~L}$ TWW sample was collected in May 2009 from the irrigation pond upstream of the perimeter. The effluent sample was centrifuged at $1000 \mathrm{rpm}$ for $10 \mathrm{~min}$ and then filter-sterilized using a $0.45 \mu \mathrm{m}$ membrane filter (Millipore, Billerica, MA, USA) for chemical analysis.

A soil profile from the TWW-irrigated area was sampled at five depths: 10, $20,40,60$ and $90 \mathrm{~cm}$. In addition, a control soil profile was taken from the rainfed area at only two depths: 10 and $40 \mathrm{~cm}$, due to the soil homogeneity beyond this depth, fig.1. The soil samples were homogenized and conditioned in

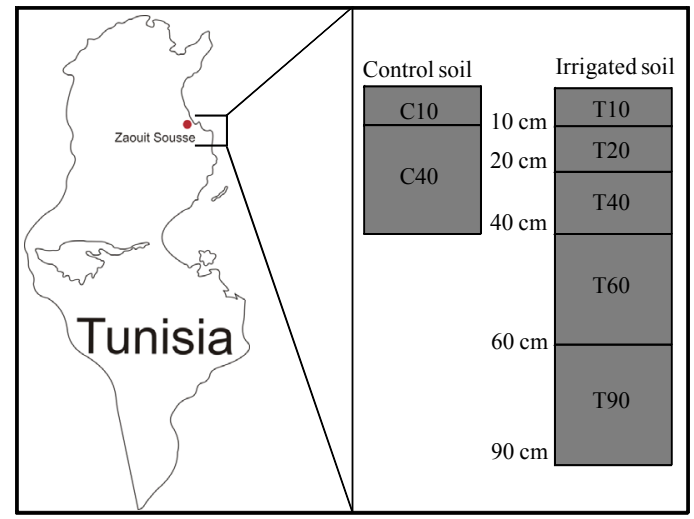

Figure 1: Sampling site. 
plastic containers. The samples were dried overnight at $40^{\circ} \mathrm{C}$ and then sifted to 2 $\mathrm{mm}$. Soil extracts $1: 5$ ( $2 \mathrm{~g}$ of soil in $10 \mathrm{ml}$ of deionized water) were prepared, centrifuged at $2000 \mathrm{rpm}$ for $30 \mathrm{~min}$ and then filtered at $0.45 \mu \mathrm{m}$ for chemical analysis. For the sample volume used for bioassays experiments, $\mathrm{pH}$ was adjusted to the $\mathrm{pH}$ range of 5-6 prior to addition to the cells and then filtersterilized at $0.22 \mu \mathrm{m}$ in order to maintain optimum conditions for cells culture.

Electric conductivity (EC) and $\mathrm{pH}$ were measured using a YK-22CT conductivity meter (Sato Shouji Inc., Tokyo, Japan) and a UC-23 digital pH meter (Central Kagaku Corp., Tokyo, Japan), respectively. Ni, Cd, Pb, Fe and Al contents were determined following the standard methods of analysis 8150 PAN, 8033 Dithizone, 8317 fast column extraction, 8112 Aluminon, and 8147 Ferrozine respectively, using DR/4000 Spectrophotometer (Hach, Loveland, CO, USA).

\subsection{Cells and culture conditions}

Chinese hamster ovary $(\mathrm{CHO})$ cells stably transfected with $(+)$ or without $(-)$ a HSP 47 promoter were used for this experiment. HSP 47-promoter-transfected cells will be abbreviated into HSP(+). The cells were provided by Dr. S. Yokota of Kaneka Corp. (Osaka, Japan) and were grown as adherent monolayer in 75 $\mathrm{cm}^{2}$ tissue culture flasks using F12 Medium (Invitrogen, Carlsbad, CA, USA) supplemented with 10\% Fetal Bovine Serum (FBS) (Biowest, Nuaillé, France), $200 \mu \mathrm{g} / \mathrm{mL}$ of Geneticin (G418) (Invitrogen, Carlsbad, CA, USA), and $0.1 \mathrm{~g} / \mathrm{L}$ kanamycin solution (Sigma-Aldrich, St Louis, MO, USA). Estrogen receptorpositive human breast cancer MCF-7 cells were obtained from Dr. H. Shinmoto of the National Food Research Institute, Ministry of Agriculture, Fishery and Forestry (Tsukuba, Japan) and routinely maintained in RPMI 1640 (Invitrogen, Carlsbad, CA, USA) supplemented with $10 \% \mathrm{FBS}$ and $1 \%$ penicillin (5000 $\mu \mathrm{g} / \mathrm{mL}$ )-streptomycin $(5000 \mathrm{IU} / \mathrm{mL})$ solution (MP Biomedicals LLC, Aurora, $\mathrm{OH}$, USA) in $75 \mathrm{~cm}^{2}$ tissue culture flasks. The cultures were maintained in a $5 \%$ $\mathrm{CO}_{2}$ incubator at $37^{\circ} \mathrm{C}$. Cell passage was carried out at $80 \%$ confluence at $1: 2$ ratio using $0.25 \%$ trypsin ( $1 \mathrm{mM}$ ethylenediaminetetra-acetic acid (EDTA)).

\subsection{HSP 47 assay}

Following exposure to environmental stressors such as heavy metals, HSP 47 promoter-transformed $\mathrm{CHO}$ cells synthesize protecting proteins from cellular damage [7]. Heat Shock proteins, the biomarkers of environmental stress, are expressed and a reporter gene $\beta$-galactosidase connected to stress-responding promoter is transferred into a chromosome. The assay was performed by measuring the $\beta$-galactosidase activity induced in response to wastewater or soil extract treatment, as described previously with some modifications [8]. $\mathrm{HSP}(+)$ cells were trypsinized and plated onto 96 well plates at initial concentrations of $1 \times 10^{4}$ cells per well in $100 \mu \mathrm{L}$ of culture medium. The cells were allowed to attach for $48 \mathrm{~h}$ before removing medium and then $100 \mu \mathrm{L}$ of sample diluted with medium was added and incubated for $3 \mathrm{~h}$ in a $5 \% \mathrm{CO}_{2}$ incubator at $37{ }^{\circ} \mathrm{C}$. The TWW samples were added at the concentrations of $0.01,0.1,1,5,10$, and $20 \%$, whereas the soil extracts were used at $0.001,0.01,0.1,1,5$, and $10 \%$ 
concentrations. For higher concentrations than $1 \%$, the results in wells with $5 \%$ sample were compared with those with $5 \%$ phosphate-buffered saline (PBS(-)) and so on, in order to distinguish between the sample effect and the decrease of medium volume. After incubation with the samples, the medium was carefully removed and the cells were washed twice with PBS(-). Fifty microliters of lysis buffer (Promega, Tokyo, Japan) was added and the plates were incubated for 30 min at room temperature. Twenty microliters of cell lysate was transferred to a new plate, to which $100 \mu \mathrm{L}$ of substrate solution $\left(10 \mathrm{mM} \mathrm{NaH}_{2} \mathrm{PO}_{4} 2 \mathrm{H}_{2} \mathrm{O}, 100\right.$ $\mathrm{mM} \mathrm{NaCl}, \quad 0.1 \% \quad \mathrm{BSA}, \quad 0.05 \% \quad \mathrm{NaN}_{3}, \quad 1 \quad \mathrm{mM} \quad \mathrm{MgCl}_{2} 6 \mathrm{H}_{2} \mathrm{O}, \quad 1 \% \quad 4-$ methylumbelliferyl- $\beta$-galactose (MUG) in dimethyl sulfoxide, $\mathrm{pH} 7.0$ ) was added in order to trigger the conversion of MUG into $\beta$-galactose and methylumbelliferyl by $\beta$-galactosidase [8], the gene of which is downstream of the HSP 47 promoter. After allowing the reaction to occur in the dark for $30 \mathrm{~min}$ at room temperature, $60 \mu \mathrm{L}$ of buffer ( $1 \mathrm{M}$ glycine- $\mathrm{NaOH}, \mathrm{pH} 10.3)$ was added to stop the reaction and the fluorescence at $365 \mathrm{~nm}$ excitation/ $450 \mathrm{~nm}$ emission was then measured using a multidetection microplate reader (Powerscan HT; Dainippon Pharmaceutical, Osaka, Japan).

\subsection{Modified E-screen assay}

The estrogenic activity of the samples was investigated using the E-screen assay. Human breast cancer MCF-7 cells were plated onto 96 well plates at 1000 cells per well in $100 \mu \mathrm{L}$ of phenol-red-free RPMI medium supplemented with $10 \%$ charcoal-treated FBS. They were then allowed to attach for $48 \mathrm{~h}$. The TWW and the soil extract samples were added to the cells at the same concentrations tested for the HSP 47 assay. Seventeen- $\beta$-estradiol (E2) (Sigma-Aldrich, St Louis, MO, USA) in $\mathrm{Ca}^{2+}$ and $\mathrm{Mg}^{2+}$ free PBS(-) (29 $\mathrm{nM}$ final concentration) was used as positive control. For higher concentrations than $1 \%$, the results in wells with $5 \%$ sample were compared with those with $5 \% \operatorname{PBS}(-)$ and so on. The cells were incubated for 6 days, after which, cell number was assessed by 3-(4,5dimethylthiazol- 2-yl)-2,5-diphenyl-2H-tetrazolium bromide (MTT) assay as follows: $10 \mu \mathrm{L}$ of $5 \mathrm{mg} / \mathrm{mL}$ MTT (Dojindo, Tokyo, Japan) was added to each well, followed by incubation for $24 \mathrm{~h}$. Sodium dodecyl sulfate (SDS, $10 \%$ ) was then added at $100 \mu \mathrm{L}$ per well, followed by incubation for another $24 \mathrm{~h}$. The absorbance was then determined at $570 \mathrm{~nm}$ using a multidetection microplate reader (Powerscan HT; Dainippon Pharmaceutical, Osaka, Japan).

\subsection{Proteomics analyses}

Human breast cancer MCF-7 cells were plated onto Petri plates at $2 \times 10^{6}$ cells/plate in $10 \mathrm{ml}$ of medium and then allowed to attach for $24 \mathrm{~h}$. Concentrations derived from the E-screen assay results were selected. So that, TWW sample at $10 \%$ concentration and wastewater irrigated-soil extract sample T20 at 1\% concentration were then added to the cells. The cells were incubated for $24 \mathrm{~h}$, after which the total proteins were extracted. Two plates were used for both treatments and the untreated control. Before protein extraction, the cells were washed twice with $\operatorname{PBS}(-)$, after which $300 \mu \mathrm{l} /$ plate of lysis/extraction solution (7 M urea, $2 \mathrm{M}$ thiourea, 4\% (w/v) 3-[(3-cholamidopropyl) 
dimethylammonio]-1-propanesulfonate (CHAPS), $1 \mathrm{mM}$ EDTA, $25 \mathrm{mM}$ spermine base, $50 \mathrm{mM}$ dithiothreitol (DTT), and $10 \mu \mathrm{l} / \mathrm{ml}$ protease inhibitor) was added and the cells then scraped and transferred to a polyallomer microultracentrifuge tube. Extraction was carried out at room temperature for 60 min with occasional mixing. The sample was then centrifuged at $130000 \mathrm{~g}$ for $100 \mathrm{~min}$ at $15{ }^{\circ} \mathrm{C}$. The protein-containing supernatant was kept in low binding Eppendorf tubes and the protein concentration was determined using the 2D Quant Kit (Amersham Biosciences, Uppsala, Sweden). For first-dimension electrophoresis, $24 \mathrm{~cm}$-immobilized $\mathrm{pH}$ gradient (IPG) dry strips (Amersham Biosciences, Uppsala, Sweden) were rehydrated for $24 \mathrm{~h}$ with $350 \mu \mathrm{g}$ of the extracted protein diluted in rehydration buffer (7 M urea, $2 \mathrm{M}$ thiourea, $2 \%(\mathrm{w} / \mathrm{v})$ CHAPS, $0.002 \%$ bromophenol blue (BPB), $10 \mathrm{mM}$ DTT and $0.5 \%(\mathrm{v} / \mathrm{v})$ IPG buffer ( $\mathrm{pH}$ 3-10) (Amersham Biosciences, Uppsala, Sweden)) according to the manufacturer's instructions. Using the Ettan IPGphor II (Amersham, Uppsala, Sweden) apparatus, the proteins were then separated according to their isoelectric point under conditions provided in the 2D protocol. For seconddimension electrophoresis, the isoelectrically focused IPG strips were then equilibrated with DTT and iodoacetamide following the manufacturer's instructions. Each strip was then applied onto a gradient SDS-PAGE gel (18\% $(\mathrm{w} / \mathrm{v})$ polyacrylamide) and the proteins separated according to their molecular weight using Ettan Daltsix Electrophoresis System (Amersham Biosciences, Uppsala, Sweden). Immediately after electrophoresis, the proteins were visualized by Cloomassie Brilliant Blue (CBB) staining using the PastGel Blue R-350, (Amersham Biosciences, Uppsala, Sweden) following the manufacturer's instructions. The stained gels were scanned using Image-Scanner (Amersham Biosciences, Uppsala, Sweden) and the spots were analyzed using the ImageMaster 2D Elite software (Amersham Biosciences, Uppsala, Sweden). For mass spectrometry, protein spots of interest were excised from the CBB-stained gel, washed, and digested in-gel with trypsin (sequencing grade; Promega, Tokyo, Japan)). All liquid chromatography mass spectrometry (LC/MS/MS) mass spectra were acquired on a 3200 QTAR Pulsar (Applied Biosystems, Foster, CA, USA) mass spectrometer. The obtained peptide sequence tags were used to identify proteins by searching databases using the Protein Pilot software (Applied Biosystems, Foster, CA, USA).

\subsection{Statistical analyses}

Statistical analysis was carried out using Student's t-test. Differences in means were considered significant at $\mathrm{p}<0.05$. All experiments were conducted at least three times.

\section{Results and discussion}

\subsection{Water quality parameters and heavy metal levels}

The physico-chemical parameters as well as the heavy metal content in the TWW and soil extract samples are presented in table 1. Originally, the TWW 
Table 1: $\quad$ Physico-chemical parameters and heavy metal levels.

\begin{tabular}{|c|c|c|c|c|c|c|c|}
\hline Sample & $\mathrm{pH}$ & $\mathrm{EC}(\mathrm{ms} / \mathrm{cm})$ & $\mathrm{Ni}(\mu \mathrm{g} / \mathrm{l})$ & $\mathrm{Cd}(\mu \mathrm{g} / \mathrm{l})$ & $\mathrm{Pb}(\mu \mathrm{g} / \mathrm{l})$ & $\mathrm{Al}(\mu \mathrm{g} / \mathrm{l})$ & $\mathrm{Fe}(\mu \mathrm{g} / \mathrm{l})$ \\
\hline $\mathrm{TWW}$ & 8.18 & 1.990 & 25 & 172.50 & - & 140 & 105 \\
\hline $\mathrm{T} . \mathrm{S}^{\mathrm{a}}$ & $6.5-8.5$ & 7.000 & 200 & 10.00 & 1000 & 5000 & 5000 \\
\hline $\mathrm{C} 10$ & 7.67 & 0.056 & 10 & 73.08 & - & 150 & 50 \\
\hline $\mathrm{C} 40$ & 7.78 & 0.100 & 5 & 42.50 & - & 250 & 65 \\
\hline $\mathrm{T} 10$ & 7.82 & 0.393 & 50 & 92.50 & - & 160 & 85 \\
\hline $\mathrm{T} 20$ & 7.73 & 0.174 & 285 & 85.00 & - & 1310 & 130 \\
\hline $\mathrm{T} 40$ & 7.95 & 0.271 & 95 & 65.72 & - & 830 & 50 \\
\hline $\mathrm{T} 60$ & 8.17 & 0.274 & 95 & 65.00 & - & 530 & 80 \\
\hline T90 & 8.17 & 0.203 & 150 & 205.00 & - & 830 & 30 \\
\hline EU.S & & & $6-15$ & $0.2-0.6$ & $10-60$ & - & - \\
\hline US.S $^{\mathrm{b}}$ & & & $6-42$ & 4 & - & - & - \\
\hline
\end{tabular}

${ }^{\mathrm{a}}$ Tunisian standards for wastewater reuse [1]; ${ }^{\mathrm{b}}$ International standards for soils [9].

was characterized a by high salinity with a mean EC value of $3.5 \mathrm{~ms} / \mathrm{cm}$. Following the filtration at $0.45 \mu \mathrm{m}$, the EC of the TWW decreased to $1.99 \mathrm{~ms} / \mathrm{cm}$ below the Tunisian standards indicating the presence of lower amounts of salts and impurities. For the irrigated soil profile and for all the horizons, the EC is higher than those of the control soil. A part from the top soil (i.e. $10 \mathrm{~cm})$, the EC values increased in depth.

Our previous results [9] revealed the presence of several heavy metals in the TWW and the soil extracts. For this reason, we targeted five heavy metals Ni, $\mathrm{Cd}, \mathrm{Pb}, \mathrm{Al}$ and $\mathrm{Fe}$, highly relevant to human exposure, through detecting their residual levels in the samples. Overall, the heavy metal levels in the TWW sample fitted the local guidelines. Previously, Angelakis [1] sustained the idea that heavy metals predominantly accumulate in sludge and not in the liquid wastewater. However, the Cd content in the TWW was broadly much higher than the Tunisian standard of $10 \mu \mathrm{g} / \mathrm{l}$ (over 17-times).

The migration of metals to the soil will especially depends on the concentration of organic carbon and the soil nature. We antecedently [9] found that the irrigated soil has a sandy-clay texture up to $40 \mathrm{~cm}$ depth followed by a sandy texture for deeper horizons. The sandy nature will allow the infiltration of pollutants, while the clay fraction might be responsible of pollutants adsorption. Moreover, the $\mathrm{pH}$ values for the irrigated soil vary between 7.82 and 8.17 . The highest values, which could favor metal binding to biomass [10], are localized in depth. Overall, the heavy metal levels in the irrigated soil were higher than the control soil ( $\mathrm{C} 10$ and $\mathrm{C} 40$ ) due to the prolonged irrigation (20 years).

For the treated soil, $\mathrm{Ni}, \mathrm{Al}$ and $\mathrm{Cd}$ profiles showed a similar trend with high levels in the top soil at $20 \mathrm{~cm}$ and in depth beyond $90 \mathrm{~cm}$. Nevertheless, only the $\mathrm{Cd}$ level revealed to be higher than EU and US guidelines for both the irrigated and control soil. On the other hand, with a detection limit of $2 \mu \mathrm{g} / \mathrm{L}, \mathrm{Pb}$ was not detected for both the TWW and the soil extract samples.

We hypothesized that the heavy metals, present in the samples, could be responsible for inducing stress response on mammalian cells. Thus, the HSP 47 assay was carried out aiming to verify this assumption. 


\subsection{Stress response effect of the wastewater effluent and the soil extract samples on $\mathrm{HSP}(+)$ cells}

Heat shock proteins (HSPs) are a distinctive class of molecules that protect cells against a wide range of injuries. They assist in the recovery of stress either by repairing damaged proteins or by removing them to restore protein homeostasis [7]. In this respect, it is known that the stress response system, in particular the HSP inducing system, functions in all mammalian tissues and cells. Therefore, in bioassay systems utilizing this stress response, it is not necessary to take into consideration the basic problems regarding cell specificity [8]. Collagen, which is the only substrate protein for HSP 47 , is the main component of cartilage, ligaments, tendons, bone and teeth, and is responsible for maintaining strength and elasticity of many soft tissues, including skin and blood vessels [7]. Accordingly, assessing the stress response pathway related to HSP 47 expression is with high relevance for human health. It has already been revealed that the production of stress proteins is induced as a result of the reaction of cells with a stressor such as heat, a chemical substance or a heavy metal, fig. 2. We previously [8] developed this highly sensitive system, HSP 47 assay, for detecting trace amounts of environmental pollutants and natural toxins.

The stress response of $\mathrm{HSP}(+)$ cells exposed to the TWW from Sousse South STP was estimated using the HSP 47 assay. Interestingly, the results showed that the TWW samples exhibited a dose dependent stress response with a peak registered at $1 \%$ concentration. Nevertheless, higher concentrations above $1 \%$ caused a cytotoxic effect even significant at $20 \%$ concentration. The stress response induced by the TWW samples might be related to the Cd content (Table 1) combined to a mixture of heavy metals responsible of a significant stress response in accordance with our recent works [10].

The stress-inducing effect of irrigated or rainfed soil extract samples, taken at several depths, was also investigated .When the stress response of $\mathrm{HSP}(+)$ cells was tested, 3 h-treatment with irrigated soil extract samples at $1 \%$ concentration

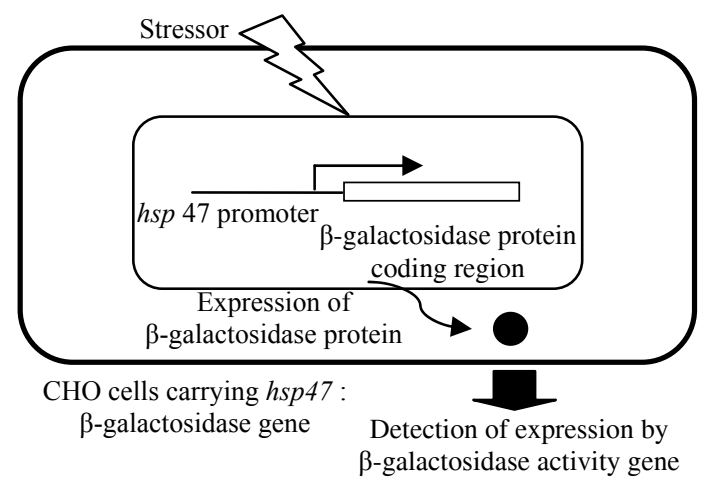

Figure 2: $\quad$ HSP 47 assay overview. 
induced the highest effect similarly to the wastewater effect with a continuous increase for the lower concentrations followed by a decreasing trend for the higher concentrations (i.e. more than 1\%) except for T90 sample, fig.1. Interestingly, no significant stress was observed for the control soil extract samples at both depths $\mathrm{C} 10$ and $\mathrm{C} 40$, fig.1. Moreover, the highest stress response was induced by T20 and T90 in accordance with the heavy metal profile trend showing the highest content for the same samples. These results might be correlated with previous observations in Malta where soil monitoring has shown a salt accumulation in the top soil during the irrigation season followed by leaching to the groundwater with the winter rains [1]. Additionally, Palese et al. [6] showed that the top $10 \mathrm{~cm}$ of TWW-irrigated soil accumulated Enterococci and sulfite reducing clostridium spores during the irrigation season.

In addition to the stress-inducing compounds, we aimed to examine the presence of estrogenic or other toxic compounds.

\subsection{Estrogenic activity of the samples of the wastewater effluent and the soil extract samples on MCF-7 cells}

The E-screen assay was carried out for the TWW and the soil extracts in order to detect the presence of estrogenic compounds and other toxic compounds in the samples as well as their potential accumulation in the soil, fig.3. The proliferation levels of the human breast cancer MCF-7 cells incubated with the TWW samples were significantly different from that of the non-treated control, starting from $1 \%$ final concentration ( $\mathrm{t}$-test, $\mathrm{p}<0.05$ ). The effluent sample at $10 \%$ concentration was able to induce an estrogenic activity of 2.2-times of the control cell activity. The latter concentration caused an estrogenic activity almost equal to the positive control (17- $\beta$-estradiol (E2)) and was consequently chosen for further proteomics analyses.

Using MCF-7 cells, we determined by the E-screen assay whether the soil extract samples can induce a significant estrogenic activity. Overall, the samples revealed to be more cytotoxic on the surface soil $(0-20 \mathrm{~cm})$ rather than in depth $(90 \mathrm{~cm})$. The possible presence of cytostatic or cytotoxic compounds accumulated on the soil may explain the significant decrease in cell number

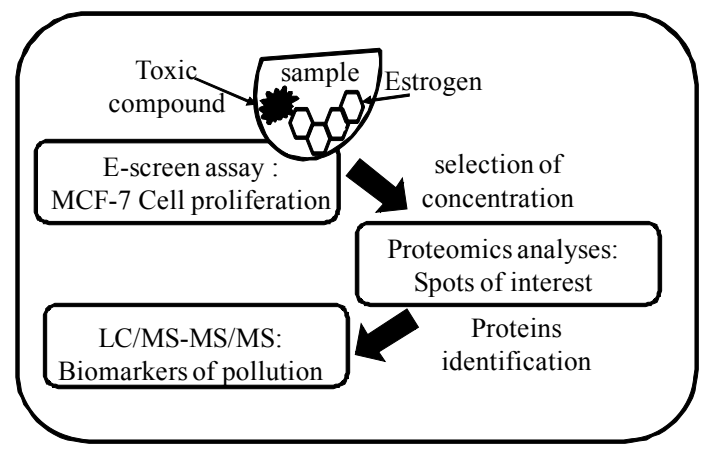

Figure 3: Methodology of the establishing biomarkers. 


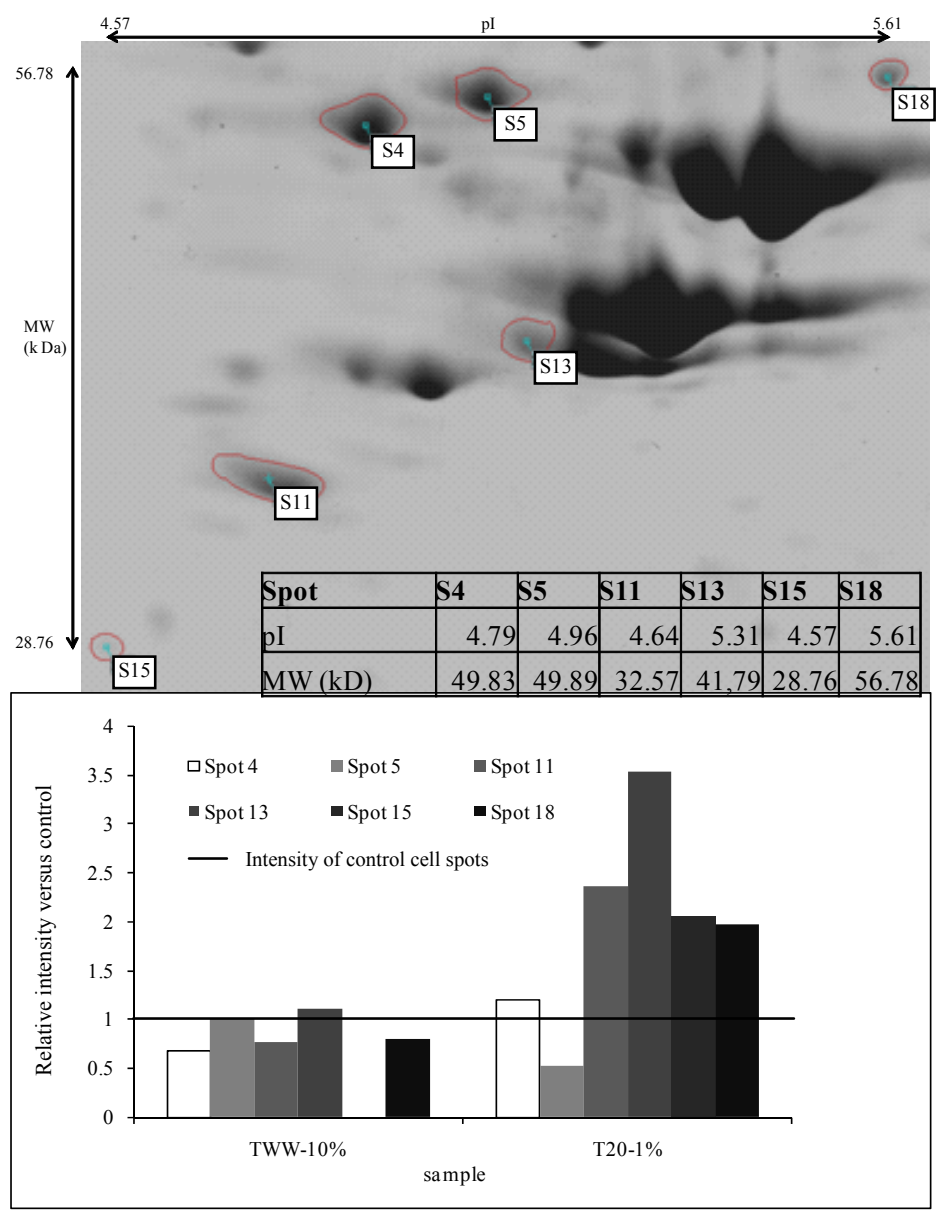

Figure 4: Comparison of spot intensity among two-dimensional protein profiles of human breast cancer MCF-7 cells incubated for $24 \mathrm{~h}$ with or without TWW at $10 \%$ concentration and soil extract from Zaouit Sousse perimeter at $20 \mathrm{~cm}$ depth (T20) and $1 \%$ concentration. Six spots of interest from CBB-stained gels are shown with their corresponding isoelectric points (pI) and molecular weights (MW).

versus that of the non-treated control. Among the different profiles and concentrations T20 at 1\% concentration was selected for further investigation by the proteomics analyses, fig. 3 . Indeed, the $10 \mathrm{~cm}$ top soil was not considered to prevent from the interference of occasional contamination. The latter is probably due to a number of factors, such as grazing of livestock, presence of wild animals and surface water runoff from adjacent agricultural areas [6]. On the 
other hand, $1 \%$ concentration was revealed to be incontestably cytotoxic and was thus selected to check the impact of wastewater reuse at protein level.

\subsection{Proteomics analyses}

In order to evaluate the quality of water in terms of the presence of potentially toxic substances and the accumulation of pollutants in soil, it is important to perform preliminary toxicological tests and to check cellular impacts at protein level in irrigated soil [1]. Following the results given by the E-screen assay, the sample T20 at 1\% concentration and the TWW sample at $10 \%$ were selected for investigating the protein changes relative to the cytotoxic effect and the estrogenic activity, respectively. Fig. 4 showed that the expression of spots 4, 11 and 18 was reduced following the TWW sample exposure at $10 \%$. Moreover, the protein represented by Spot 15 was not even expressed. Our target is to identify these proteins of interest and to reveal their implication in some tumors or diseases with high relevance for human health. Following the exposure of human intestinal epithelium Caco-2 cells to urban TWW, we previously $[11,12]$ demonstrated the expression of elongation factor- $\beta$ and HSP90- $\beta$ involved in allergic reaction and stress response, respectively.

Proteomics analyses revealed that MCF-7 cells incubated for $24 \mathrm{~h}$ with the irrigated soil extract T20 at 1\% final concentration showed enhanced expressions of four protein spots of interest, spots 11, 13, 15 and 18, fig.1. Application of proteomics analyses to such samples is relatively new. Mass spectrometry will be able to identify the target proteins as biomarkers of wastewater reuse pollution.

\section{Conclusion}

Heavy metals or other toxic compounds accumulated on soil irrigated with TWW threaten soil, groundwater and human health. Hence, targeting the risk assessment of wastewater reuse is with a great concern. In the present study we tried to investigate the pollution pathway from the TWW to the soil by monitoring environmental stressors such as heavy metals and estrogenic compounds. Likewise, we attempted to establish specific biomarkers of wastewater reuse. The obtained results have shown that HSP 47 assay is a high sensitive system that could be used for studying the effect of heavy metal mixture introduced to the soil by the TWW. Coupling the E-screen assay to the proteomics analyses has proven to be useful for establishing specific biomarkers for estrogenicity or cytotoxicity related to wastewater reuse. Nevertheless, future risk assessment studies including leaves or fruits of several trees or crops could be useful to better understand the pathway of pollution.

\section{Acknowledgement}

This research was partially supported by the Mitsui \& Co., Ltd. Environment Fund. 


\section{References}

[1] Angelakis A.N., Marecos Do Monte, M.H.F., Bontoux, L. \& Asano, T., The status of wastewater reuse practice in the Mediterranean basin: need for guidelines. Water research, 33, pp. 2201-2217, 1999.

[2] Bahri, A. \& Brissaud, F., Wastewater reuse in Tunisia: assessing a national policy. Water Sci and Technol, 33, pp. 87-94, 1996.

[3] Blumenthal, U.J., Peasey, A., Ruiz-Palacios, G. \& Mara, D.D., Guidelines for wastewater reuse in agriculture and aquaculture: recommended revisions based on new research evidence. London School of Hygiene \& Tropical Medicine, UK \& WEDC, Loughborough University, UK, pp. 9, 2000

[4] Gupta, N., Khan, D.K. \& Santra S. C., An assessment of heavy metal contamination in vegetables grown in wastewater-irrigated areas of Titagarh, West Bengal, India. Bull Environ Contam Toxicol, 80, pp. 115$118,2008$.

[5] Al-Khashman, O.A., Chemical evaluation of Ma'an sewage effluents and its reuse in irrigation Purposes. Water Resour Manage, 23, pp. 1041-1053, 2009

[6] Palese, A.M., Pasquale, V., Celano, G., Figliuolo, G., Masi, S. \& Xiloyannis, C. Irrigation of olive groves in Southern Italy with treated municipal wastewater: Effects on microbiological quality of soil and fruits. Agriculture, Ecosystems and Environment, 129, pp. 43-51. 2009.

[7] Lewis, S., Handy, R.D., Cordi, B., Billinghurst, Z. \& Depledge, M.H., Stress proteins HSP's: Methods of detection and their use as an environmental biomarker. Ecotoxicology, 8, pp. 351-368. 1999.

[8] Isoda, H., Koyama, T., Tasaki, M., Oka, S., Sugiura, N., Maekawa, T., Inamori, Y., Yokota, S., Kitahara, M. \& Nagata, K. High-sensitive detection of environmental pollutants. US Patent and Trademark office US006740521B2. Washington, DC, 2003.

[9] Klay, S., Charef, A, Ayed, L., Houman, B. \& Rezgui, R., Effect of irrigation with treated wastewater on geochemical properties (saltiness, C, $\mathrm{N}$ and heavy metals) of isohumic soils (Zaouit Sousse perimeter, Oriental Tunisia). Desalination, 253, pp.180-187. 2010.

[10] Ben Fredj, F., Irie, M., Han, J., Yamada, P., Limam, A. Ghrabi, A., Morio, T. \& Isoda, H., Stress response of heavy metal mixture present in wastewater and leachate on HSP 47-transformed cells. Environ. Tox and Chem. In press, 2010.

[11] Funamizu, N., Takenaka, M., Han J. \& Isoda H., Application of heat shock protein assay and proteome assay to water from wastewater treatment plant. Water Sci and Technol, 57(8), pp. 1183-1189, 2008.

[12] Narita, H., Talorete, T. P. N., Han, J., Funamizu, N. \& Isoda, H., Human intestinal cells incubated with activated sludge and lipoposaccharide express Hsp90b. Environ. Sci, 14, pp. 35-39. 2007. 